\title{
Formulation and Evaluation of Fast Dissolving Film of Losartan Potassium
}

\author{
Bhageerathy A*, Sandhya Murali, Teny Sara Thomas, Sigi Vasanthkumar, Prasanth V V \\ 1Department of Pharmaceutics, Mount Zion College of Pharmaceutical Sciences and Research. \\ Chayalode P.O. Ezhamkulam, Adoor, Pathanamthitta, Kerala - 691556, India. \\ *Corresponding author's E-mail: bhageerathyiyer@gmail.com
}

Received: 18-02-2021; Revised: 25-04-2021; Accepted: 05-05-2021; Published on: 15-05-2021. \begin{abstract}
A total of nine formulations of fast dissolving films of Losartan Potassium were developed by solvent casting method using film forming polymers such as HPMC E5, E15 and E50 and other film modifiers. The appearances of films were transparent, thin, flexible, elastic, smooth and transparent. The weight variation ranged between $16.14 \pm 0.192$ and $17.31 \pm 0.313$ and showed that there was no significant difference in the weight of individual formulations. All the formulations showed more than 150 of folding endurance. The drug content was found to be in an acceptable range for all the formulations which indicated uniform distribution of drug. A rapid dissolution of all the film was observed by the dissolution test, in which above $90 \%$ of Losartan Potassium was released within 5 min. The formulation F1 showed maximum drug release (98.73) within 5 minutes. Based on the in vitro drug release, drug content and in vitro disintegration time it is found that F1 was selected as the best formulation. The formulations showed satisfactory physical stability at $40^{\circ} \mathrm{C}$ at $75 \% \mathrm{RH}$. Losartan Potassium (LOSAR-25) is shown in Figure 4. From the results of comparative studies of marketed product and it found that F1 showed $98.73 \%$ release within 5 min and LOSAR 25 showed $90.76 \%$ release in 30 min. In vitro studies indicate that this potential drug delivery system has considerably good stability and release profile. Nevertheless, further in vivo studies are warranted to confirm these results.
\end{abstract}

Keywords: Fast dissolving, Films, Folding endurance, In vitro release, Stability studies.

QUICK RESPONSE CODE $\rightarrow$

DOI:

10.47583/ijpsrr.2021.v68i01.036

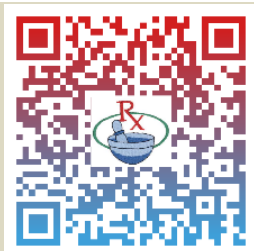

DOI link: $\underline{\text { http://dx.doi.org/10.47583/ijpsrr.2021.v68i01.036 }}$

\section{INTRODUCTION}

O ral route of administration is the most accepted route for therapeutic agents because of the low cost and ease of administration lead to high levels of patient compliance. About $60 \%$ of all dosage forms are the oral solid forms and the most accepted oral solid dosage forms are tablets and capsules ${ }^{1}$. The oral drug delivery systems still need some advancement to be made because of their some drawbacks related to particular class of patients which includes geriatric, pediatric and dysphasic patients associated with many medical conditions as they have difficulty in swallowing or chewing solid dosage forms. Many pediatric and geriatric patients are disinclined to receive solid preparations due to fear of choking dosage forms. One study showed that $26 \%$ of patients practiced difficulty in swallowing tablets. The most general complaint was tablet size, followed by surface form and taste. The difficulty of swallowing tablets was more evident in geriatric and pediatric patients, as well as travelling patients who may not have ready access to water ${ }^{2}$.
Fast-dissolving film systems can be an alternative to tablets, capsules and syrups for pediatric and geriatric patients who experience difficulties in swallowing traditional oral solid-dosage forms. The purpose of the present study was to formulate the fast dissolving film of Losartan Potassium with an aim to achieve speedy absorption of drug and further improving the bioavailability of the drug. Also, to resolve the swallowing troubles in pediatric, geriatric patients by quick dissolution in saliva and advance the patient compliance.

\section{MATERIALS AND METHODS}

\section{Materials}

Losartan Potassium and HPMC E5, E15, E50 were obtained as a free gift sample from Yarrow Chem Products, Mumbai, India. All other reagents like polyethylene glycol, tween 80, xanthan gum, citric acid and saccharin sodium are procured from Chemdyes Corporation, Rajkot, India.

\section{Methods}

\section{Formulation of fast dissolving film of Losartan Potassium}

Fast dissolving films of Losartan Potassium were developed by solvent casting method using film forming polymers such as HPMC E5, E15 and E50 and other film modifiers (Table 1). Above these two are weighed accurately and soaked with water. Simultaneously the required amount of Losartan Potassium is dissolved in sufficient quantity of water. This prepared solution were added to the previously prepared polymeric solution and 
mixed well to get a homogenous solution followed by other excipients (plasticizers, saccharin sodium and citric acid). This homogenized solution was poured into petridishes. The solvent was allowed to evaporate by inverting a glass funnel plugged with cotton in the stem at room temperature for 24 hours. After complete evaporation of solvent, films were obtained and the resultant film was cut into the uniform dimension $(2 \mathrm{~cm} \times$ $2 \mathrm{~cm})$, which were then wrapped in an aluminum foil and stored in a dessicator ${ }^{3}$.

Table 1. Formulation of fast dissolving films of Losartan Potassium

\begin{tabular}{|c|c|c|c|c|c|c|c|c|c|}
\hline Ingredients & $\mathbf{F}_{1}$ & $\mathbf{F}_{2}$ & $\mathbf{F}_{3}$ & $\mathbf{F}_{4}$ & $\mathbf{F}_{5}$ & $\mathbf{F}_{6}$ & $F_{7}$ & $F_{8}$ & $F_{9}$ \\
\hline Losartan Potassium (mg) & 400 & 400 & 400 & 400 & 400 & 400 & 400 & 400 & 400 \\
\hline $\mathrm{HPMC} \mathrm{E}_{5}(\mathrm{mg})$ & 300 & 450 & 600 & - & - & - & - & - & - \\
\hline $\mathrm{HPMC}_{15}(\mathrm{mg})$ & - & - & - & 300 & 450 & 600 & - & - & - \\
\hline HPMC $E_{50}(m g)$ & - & - & - & - & - & - & 300 & 450 & 600 \\
\hline PEG $400(\mathrm{~mL})$ & 1.5 & 1.5 & 1.5 & 1.5 & 1.5 & 1.5 & 1.5 & 1.5 & 1.5 \\
\hline Tween $80(\mathrm{~mL})$ & 0.75 & 0.75 & 0.75 & 0.75 & 0.75 & 0.75 & 0.75 & 0.75 & 0.75 \\
\hline Citric acid (mg) & 45 & 45 & 45 & 45 & 45 & 45 & 45 & 45 & 45 \\
\hline XanthanGum (mg) & 30 & 30 & 30 & 30 & 30 & 30 & 30 & 30 & 30 \\
\hline Saccharin Sodium (mg) & 7.5 & 7.5 & 7.5 & 7.5 & 7.5 & 7.5 & 7.5 & 7.5 & 7.5 \\
\hline Distilled water $(\mathrm{mL})$ & 15 & 15 & 15 & 15 & 15 & 15 & 15 & 15 & 15 \\
\hline
\end{tabular}

\section{EVALUATIONS}

\section{Physical appearance and Morphology}

Prepared films were visually inspected for colour, clarity, flexibility and smoothness. The morphology was carried out using Scanning Electron Microscope (SEM) ${ }^{4}$.

\section{Weight Variations}

Individual batches of fast dissolving film of size $\left(2 \times 2 \mathrm{~cm}^{2}\right)$ was cut at three different places and the weight of each film was taken on an electronic balance and the average weight and standard deviation was calculated ${ }^{5}$.

\section{Thickness}

The thickness of the film $\left(2 \times 2 \mathrm{~cm}^{2}\right)$ was measured using screw gauge at three different places; averages of three values were calculated.

\section{Surface Ph}

The surface $\mathrm{pH}$ of fast dissolving films was determined in order to investigate the possibility of any side effects with in vivo. The films were allowed to swell in closed petri dish containing distilled water $(5 \mathrm{ml})$ at room temperature for 30 minutes and the $\mathrm{pH}$ was determined with digital $\mathrm{pH}$ meter.

\section{Folding endurance}

It was determined by folding the film $\left(2 \times 2 \mathrm{~cm}^{2}\right)$ at the same place repeatedly until it broke. The folding endurance was measured by calculating the number of times the film folded at the same place without breaking or cracking ${ }^{6}$.

\section{Percentage moisture loss}

This was determined by keeping the fast dissolving films in

a desiccator contains anhydrous calcium chloride. After 24 hours, the films were taken out and re-weighed and the percentage moisture loss was calculated using the formula ${ }^{7}$.

$$
\text { Moisture loss (\%) = initial weight }- \text { final weight }
$$

Initial weight $\times 100$

\section{Drug content}

The drug content was determined by dissolving the film of $4 \mathrm{~cm}^{2}$ in $100 \mathrm{ml}$ of phosphate buffer (pH 6.8) using magnetic stirrer for 30 minutes and the drug content was evaluated spectrophotometrically at $206 \mathrm{~nm}$ triplicate and average was taken ${ }^{8}$.

\section{Tensile strength and Percentage elongation}

Tensile strength of films was determined using an apparatus fabricated in the laboratory. A small strip of film was cut into $5 \mathrm{~cm}^{2}$ and fixed to the assembly. The weight required to break the film was noted and simultaneously the elongation of film was also measured ${ }^{9}$.

$$
\text { Tensile Strength }=\text { Break Force } / a b(1+\Delta \mathrm{L} / \mathrm{L})
$$

$$
\begin{array}{ll}
\mathrm{a}, \mathrm{b}, \mathrm{L} & =\text { width, thickness and length of the strip. } \\
\Delta \mathrm{L} & =\text { elongation at break. }
\end{array}
$$

The percent of elongation was mainly based on tensile strength of films. It was calculated by measuring the increase in length of the film after tensile strength using the following formula,

$$
\text { Elongation }(\%)=\quad \frac{\text { Increase in length }}{\text { Original length } \times 100}
$$




\section{In vitro disintegration time}

In vitro disintegration time was determined visually in a beaker which contains $25 \mathrm{ml}$ of phosphate buffer $(\mathrm{pH} \mathrm{6.8)}$ with swirling every $10 \mathrm{sec}$. The disintegration time is the time when the film starts to break or disintegrates. ${ }^{9}$

\section{In-vitro drug release}

The drug release study was carried out using USP dissolution apparatus (Basket Type XXIV). The dissolution was carried out in $900 \mathrm{ml}$ of phosphate buffer $(\mathrm{pH} 6.8)$ maintained at $37 \pm 0.5^{\circ} \mathrm{C}$ with $50 \mathrm{rpm}$. The samples $(5 \mathrm{ml})$ were taken at various time intervals and replaced with the same fresh buffer solution. The samples were filtered though whatmann filter paper, diluted with buffer and analyzed by UV spectrophotometer at $206 \mathrm{~nm}$. Drug release mechanism was determined by finding the best fit of the release data to Higuchi and Korsmeyer-Peppas plots. ${ }^{10}$

\section{In vitro release study of Losartan potassium marketed tablet (LOSAR 25)}

Dissolution tests were performed with the same procedure used for in vitro drug release. The samples were withdrawn at definite time intervals for 30 minutes and were assayed spectrophotometrically at $206 \mathrm{~nm}$. The percentage of cumulative Losartan potassium amounts released from the tablets was calculated. ${ }^{11,12}$

\section{RESULTS AND DISCUSSION}

Total number of nine formulations were prepared and subjected to different evaluation parameters. Among these formulations, $F_{1}$ shows maximum. The appearances of films were evaluated by visual examination such as transparent or opaque. The fabricated films were thin, flexible, elastic, smooth and transparent (Figure 1).

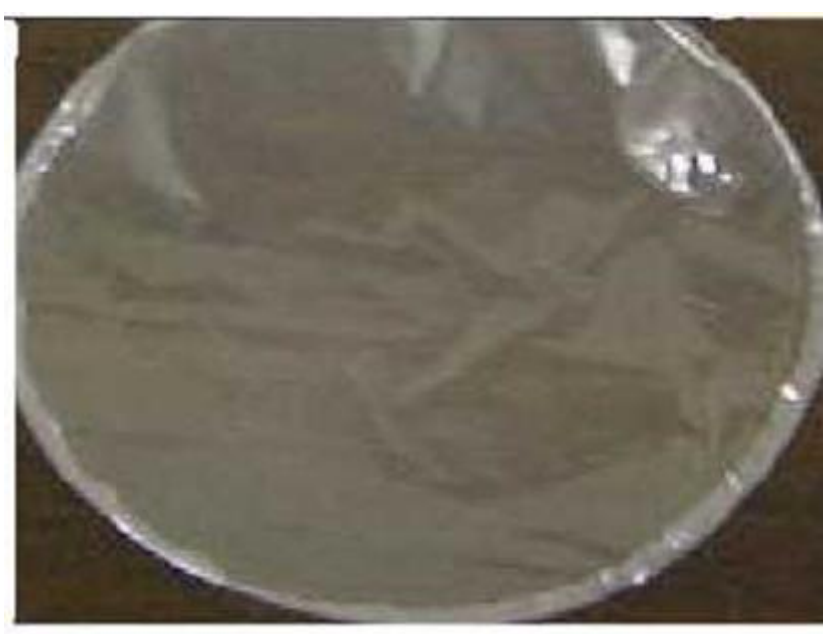

Figure 1: Appearance of film

The weight variation ranged between $16.14 \pm 0.192$ and $17.31 \pm 0.313$ and showed that there was no significant difference in the weight of individual formulations (Table 2).

This ensured uniformity of the films.
Table 2: Weight uniformity of formulations

\begin{tabular}{|l|c|}
\hline Formulation code & Weight uniformity $(\mathbf{m g})^{*}$ \\
\hline$F_{1}$ & $15.87 \pm 0.102$ \\
\hline$F_{2}$ & $15.96 \pm 0.116$ \\
\hline$F_{3}$ & $15.98 \pm 0.128$ \\
\hline$F_{4}$ & $16.14 \pm 0.192$ \\
\hline$F_{5}$ & $16.30 \pm 0.208$ \\
\hline$F_{6}$ & $16.28 \pm 0.214$ \\
\hline$F_{7}$ & $16.80 \pm 0.298$ \\
\hline$F_{8}$ & $17.10 \pm 0.301$ \\
\hline$F_{9}$ & $17.31 \pm 0.313$ \\
\hline
\end{tabular}

The thickness of all formulations was varied from $0.19 \pm 0.0043$ to $0.26 \pm 0.0024$ and ensured uniformity of film. The surface $\mathrm{pH}$ of the films was ranged from 6.72 to 7.35 and found to be around the neutral $\mathrm{pH}$ and there will not be any kind of irritation to the oral mucosa (Table 3).

Table 3: Thickness, surface $\mathrm{pH}$ of formulations

\begin{tabular}{|l|l|c|c|}
\hline $\begin{array}{l}\text { Formulation } \\
\text { code }\end{array}$ & $\begin{array}{c}\text { Thickness } \\
(\mathbf{m m})\end{array}$ & Surface $\mathbf{p H}$ & $\begin{array}{c}\text { Folding } \\
\text { endurance }\end{array}$ \\
\hline$F_{1}$ & $0.19 \pm 0.0043$ & $6.72 \pm 0.0109$ & $>150$ \\
\hline$F_{2}$ & $0.21 \pm 0.0016$ & $6.83 \pm 0.0233$ & $>150$ \\
\hline$F_{3}$ & $0.24 \pm 0.0019$ & $6.91 \pm 0.0031$ & $>150$ \\
\hline$F_{4}$ & $0.20 \pm 0.0094$ & $7.21 \pm 0.1029$ & $>150$ \\
\hline$F_{5}$ & $0.22 \pm 0.0014$ & $6.81 \pm 0.0300$ & $>150$ \\
\hline$F_{6}$ & $0.25 \pm 0.0070$ & $6.96 \pm 0.0200$ & $>150$ \\
\hline$F_{7}$ & $0.23 \pm 0.0018$ & $6.74 \pm 0.0529$ & $>150$ \\
\hline$F_{8}$ & $0.25 \pm 0.0012$ & $7.35 \pm 0.1500$ & $>150$ \\
\hline$F_{9}$ & $0.26 \pm 0.0024$ & $6.59 \pm 0.1029$ & $>150$ \\
\hline
\end{tabular}

The films were subjected to folding endurance to evaluate the flexibility studies. All the formulations showed $>\mathbf{1 5 0}$. This revealed that the prepared films were having capacity to withstand the mechanical pressure along with good flexibility. Moisture loss studies were conducted on the entire Table 4 and observed that formulation F9 showed highest amount of moisture loss and formulation F1 showed minimum percentage moisture loss. The percentage drug content in various formulations ranged from $92.73 \pm 0.19$ to $98.78 \pm 0.64 \%$ given in Table 4 . The drug content was found to be in an acceptable range for all the formulations which indicated uniform distribution of drug. In-vitro disintegration time studies (Table 4) suggested that films prepared using all these grades of HPMC E LV had in-vitro disintegration time below $50 \mathrm{sec}$ and was in acceptable range. A suitable FDF requires moderate tensile strength and good percentage elongation.

A rapid dissolution of all the films was observed by the dissolution test, in which above $90 \%$ of Losartan Potassium was released within $5 \mathrm{~min}$. The formulation F1 showed 
maximum drug release (98.73) within 5 minutes. Based on the in vitro drug release, drug content and in vitro disintegration time it is found that F1 was selected as the best formulation. All the formulations were best fitted to Higuchi model. Thus formulation F1 was selected for stability studies. No major difference was found between evaluated parameters before and after storage and all was in acceptable limits. The formulations showed satisfactory physical stability at $40^{\circ} \mathrm{C}$ at $75 \% \mathrm{RH}$. Results are showed in Table 5.

Table 4: Moisture loss, drug content and in vitro disintegration time, Tensile Strength and elongation of the formulations

\begin{tabular}{|c|c|c|c|c|c|}
\hline $\begin{array}{l}\text { Formulation } \\
\text { code }\end{array}$ & Moisture Loss & Drug Content & $\begin{array}{c}\text { In Vitro } \\
\text { Disintegration } \\
\text { time }\end{array}$ & $\begin{array}{c}\text { Tensile } \\
\text { Strength }\end{array}$ & $\begin{array}{c}\text { Elongation } \\
\text { (\%) }\end{array}$ \\
\hline $\mathbf{F}_{1}$ & $1.37 \pm 0.12$ & $98.78 \pm 0.64$ & 20 & $14.20 \pm 1.0201$ & $21.10 \pm 1.5300$ \\
\hline$F_{2}$ & $1.88 \pm 0.34$ & $96.46 \pm 0.50$ & 24 & $18.07 \pm 0.2421$ & $28.43 \pm 0.9132$ \\
\hline$F_{3}$ & $2.37 \pm 0.28$ & $95.81 \pm 0.91$ & 26 & $17.43 \pm 0.0266$ & $30.50 \pm 1.6033$ \\
\hline$F_{4}$ & $2.21 \pm 0.14$ & $97.52 \pm 1.20$ & 25 & $17.81 \pm 0.1532$ & $21.84 \pm 1.2833$ \\
\hline$F_{5}$ & $2.50 \pm 0.46$ & $94.62 \pm 3.84$ & 30 & $18.16 \pm 0.2700$ & $24.40 \pm 0.4300$ \\
\hline$F_{6}$ & $2.58 \pm 0.15$ & $93.82 \pm 0.88$ & 32 & $18.59 \pm 0.4132$ & $19.58 \pm 2.0366$ \\
\hline$F_{7}$ & $2.56 \pm 0.22$ & $96.93 \pm 1.49$ & 36 & $16.48 \pm 0.2900$ & $26.98 \pm 0.4300$ \\
\hline$F_{8}$ & $2.88 \pm 0.28$ & $95.41 \pm 0.54$ & 38 & $17.54 \pm 0.0632$ & $29.43 \pm 1.2466$ \\
\hline F9 & $3.1 \pm 0.14$ & $92.73 \pm 0.19$ & 42 & $17.91 \pm 0.1865$ & $29.01 \pm 1.1066$ \\
\hline
\end{tabular}

The in vitro drug release profiles of all the formulations is shown in (Figure 2).

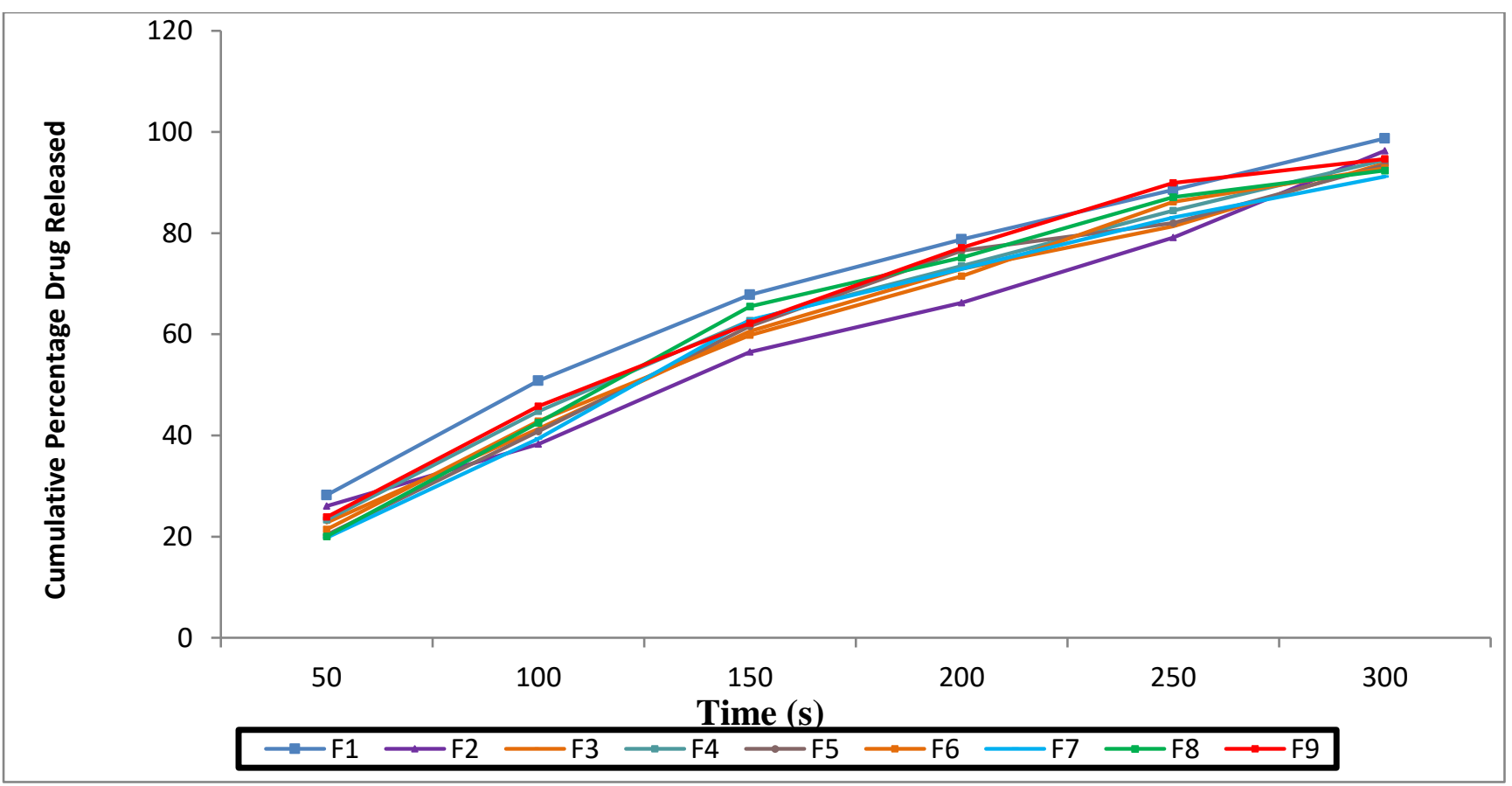

Figure 2: In vitro drug release profiles of formulations F1 - F9

Table 5: Stability studies of the best formulation

\begin{tabular}{|c|c|c|c|c|c|}
\hline Time (days) & $\begin{array}{c}\text { Physical } \\
\text { appearance }\end{array}$ & Folding endurance & Surface pH & $\begin{array}{c}\text { Drug content } \\
\text { (\%) }\end{array}$ & $\begin{array}{c}\text { Drug release } \\
\text { (\%) }\end{array}$ \\
\hline 0 & No change & $154-157 \pm 1.2$ & $6-7$ & $97.02 \pm 1.3$ & $98.73 \pm 1.6$ \\
\hline 45 & No change & $151-153 \pm 1.1$ & $6-7$ & $96.43 \pm 1.0$ & $96.78 \pm 1.1$ \\
\hline
\end{tabular}


In vitro dissolution profile of marketd product of Losartan Potassium (LOSAR-25) is shown in Figure 3. From the results it found that $\mathrm{F} 1$ showed $98.73 \%$ release with in 5 min and LOSAR 25 showed $90.76 \%$ release in $30 \mathrm{~min}$.

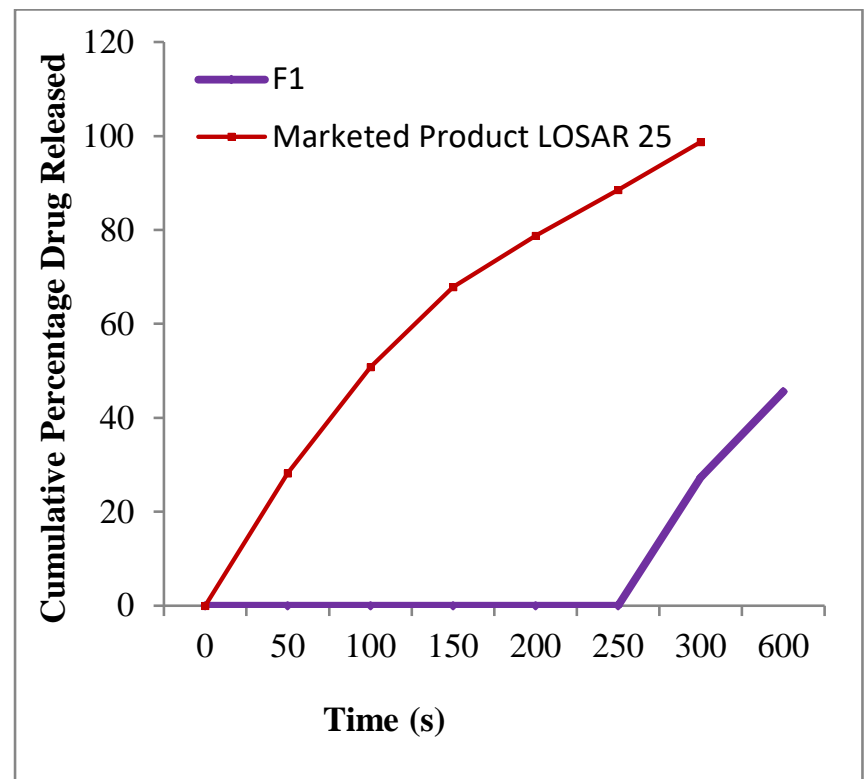

Figure 3: The in vitro drug release profile of marketed product LOSAR 25

The morphology of the selected film F1 was characterized by SEM to determine the drug distribution and it is clear that the formulation F1 shows uniform distribution of drug in (Figure 4).

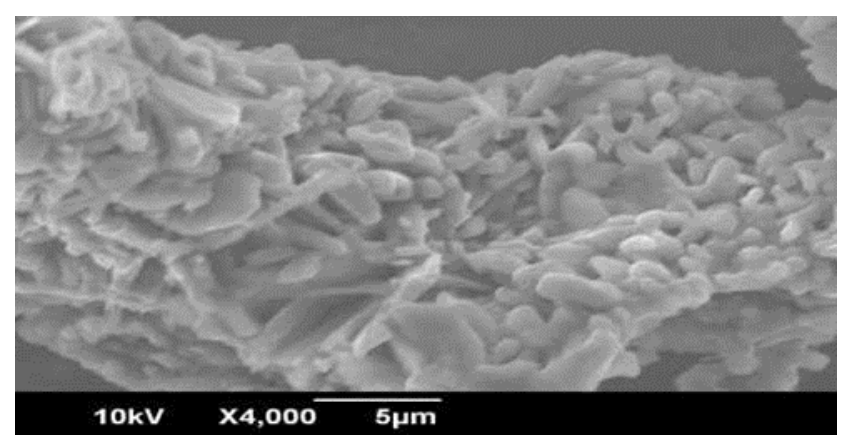

Figure 4: SEM image of the formulation F1

\section{CONCLUSION}

Fast dissolving films of Losartan Potassium were developed to overcome the first-pass metabolism and subsequent low bioavailability of the drug. In vitro studies indicate that this potential drug delivery system has considerably good stability and release profile. Nevertheless, further in vivo studies are warranted to confirm these results.

\section{REFERENCES}

1. Brahmankar DM, Jaiswal SB. Biopharmaceutics and Pharmacokinetics Treatise Vallabh Prakashan, New Delhi. , 2009; 2(1): 464-66.

2. Jitendra $P$, Patel KR, Patel NM. Review on Fast Dissolving Film: International Journal of Universal Pharmacy and Bio Sciences 2013; 2(1) :2319-8141.

3. Mahajan A, Chhabra N, Aggarwal G. Formulation and Characterization of Fast Dissolving Buccal Films: A Review, Scholars Research Library. 2011; 3(1): 152165.

4. Indian pharmacopoeia. Controller of Publications. Ministry of health and family welfare. Government of India, Delhi. 1996; 2: 144-46.

5. Desu P, Sahu.M. Formulation and Evaluation of Fast Dissolving Film of Zolmitriptan: IRJP 2012; 3(5): 37376.

6. Thakur RR, Narwal S. Orally Disintegrating Preparations Recent Advancement In Formulation and Technology: Journal of Drug Delivery \& Therapeutics 2012; 2(3): 87-96.

7. Patil SL. Fast Dissolving Oral Films: An Innovative Drug Delivery System International Journal of Research and Reviews in Pharmacy and Applied science 2012; 2(3): 482-96.

8. Kalyan S, Bansal M. Recent Trends in the Development of Oral dissolving Film International Journal of Pharm Tech Research 2012; 4(2): 725-33.

9. Panda BP, Dey NS, Rao MEB. Development of Orally Disintegrating Film Dosage Forms; a Review International Journal of Pharmaceutical Science and Nanotechnology 2012; 5(2): 1666-74.

10. Siddiqui N M, Sharma PK. A Short Review on A Novel Approach in Oral Fast Dissolving Drug Delivery System and Their Patents Advances in Biological Research 2011; 5(6): 291-303.

11. Arun A, Amrish C, Vijay S, Kamla P. Fast Dissolving Oral Films An Innovative Drug Delivery System and Dosage Form; International Journal of Chem Tech Research 2010; 2(1): 576-83.

12. Parmar D, Patel U, Bhimani B, Tripathi A. Orally Fast Dissolving Films as Dominant Dosage Form for Quick Release, International Journal of Pharmaceutical Research and Bioscience 2012; 1(3): 27- 41.

Source of Support: None declared.

Conflict of Interest: None declared.

For any question relates to this article, please reach us at: editor@globalresearchonline.net New manuscripts for publication can be submitted at: submit@globalresearchonline.net and submit_ijpsrr@rediffmail.com 